\title{
UPAYA PENINGKATAN PRODUKTIVITAS SORGUM (Sorghum bicolor L. Moench) MELALUI PUPUK BIOBOOST
}

\author{
CHAIRIL EZWARD ${ }^{1 *}$, A.HAITAMI ${ }^{1}$, ELFI INDRAWANIS ${ }^{1}$ \\ ${ }^{1}$ Program Studi Agroteknologi Fakultas Pertanian \\ Universitas Islam Kuantan Singingi, Teluk Kuantan 2019 \\ Jl. Gatot Subroto KM 7 Jake Tlpn. 081268855945 \\ Email.ezwardchairil@yahoo.com
}

\begin{abstract}
ABSTRAK
Penelitian ini bertujuan untuk Mengetahui Pengaruh Pupuk Bioboost Terhadap Produktivitas Sorgum (Sorghum bicolor L. Moench). Rancangan yang digunakan dalam penelitian ini adalah Rancangan Acak Kelompok (RAK) Non Faktorial, yaitu perlakuan Berbagai volume Pupuk Biobost terdiri dari : $\mathrm{A}=$ Tanpa perlakuan, $\mathrm{B}=$ Pemberian Pupuk Biobost $120 \mathrm{ml} \operatorname{tanaman}^{-1}, \mathrm{C}=$ Pemberian Pupuk Biobost $240 \mathrm{ml}$ tanaman $^{-1}, \mathrm{D}=$ Pemberian $^{-1}$ Pupuk Biobost $360 \mathrm{ml} \mathrm{tanaman}^{-1}, \mathrm{E}=$ Pemberian Pupuk Biobost $480 \mathrm{ml}$ tanaman $^{-1}$. Penelitian berbagai volume Pupuk Biobost terdiri dari 5 perlakuan yang diulang 3 kali. Dengan demikian penelitian ini terdiri dari 15 unit percobaan/plot, setiap unit percobaan terdiri dari 16 tanaman dan 12 diantaranya dijadikan sampel. Jumlah tanaman keseluruhan 240 tanaman. Kemudian data-data yang diperoleh di analisis secara statistik, dan di UJi Lanjut Beda Nyata Jujur (BNJ), pada taraf $1 \%$. Berdasarkan penelitian yang telah dilakukan dapat disimpulkan bahwa perlakuan volume pupuk Bioobost berpengaruh nyata terhadap semua parameter pengamatan, dimana perlakuan terbaik terdapat pada perlakuan $\mathbf{E}=$ Pemberian Pupuk Biobost $480 \mathrm{ml}$ tanaman $^{-1}$ dengan tinggi tanaman $188,33 \mathrm{~cm}$, umur muncul bunga $68,22 \mathrm{hst}$, umur panen 103,44 hst, dan berat biji kering 113,61 gram tanaman ${ }^{-1}$ setara dengan 6,05 ton ha $^{-1}$.
\end{abstract}

Kata kunci : Sorgum, Pupuk Bioboost, Volume

\section{ABSTRACT}

Research aims to understand the influence of fertilizer bioboost sorghum to productivity. Design used in this research was a random group ( shelf) non factorials, The treatment of the volume of fertilizer biobost consisting of : $A=$ Without treatment, $B=$ The provision of fertilizer biobost $120 \mathrm{ml} /$ plant, $C=$ The provision of fertilizer biobost $240 \mathrm{ml} /$ plant, $D=$ The provision of fertilizer biobost $360 \mathrm{ml} /$ plant, $E=$ The provision of fertilizer biobost $480 \mathrm{ml} /$ plant. Research various volume fertilizer biobost consisting of 5 treatment 3 times repeated. Thus this research consisting of 15 units of experiment / a plot, every unit experiment consisting of 16 plants and 12 are as sample. The quantity of a crop whole 240 plant. The results of the observation of treatment analyzed each statistically, and when markedly dissimilar will be continued by test further different real honest ( bnj ) 1 percent the first. Based on the research that has been carried out it can be concluded that treatment volume fertilizer Bioobost had have real impact on all parameter observation, where treatment is the best treatment $E=$ The provision of fertilizer biobost $480 \mathrm{ml} /$ plant, with tall plant 188,33 cm, appearing flowers age 68,22 hst, age harvest 103,44 hst, and a weight of dry 113,61 gram/tanaman setara dengan 6,05 ton $\mathrm{ha}^{-1}$.

Keywords : sorghum, fertilizer bioboost, volume 


\section{PENDAHULUAN}

FSD (2003 dan Reddy et al. 2007) melaporkan bahwa sekitar 750 juta orang yang hidup di Afrika, Asia, dan Amerika Latin yang dikenal dengan daerah Tropis setengan kering, Sorgum (Sorghum bicolor L. Moench) dijadikan sebagai pangan utama, dan sorghum sendiri menduduki peringkat kelima dari tanaman pangan penting di dunia setelah padi, gandum, jagung, dan barley.

Tanaman sorghum tidak hanya digunakan sebagai bahan pangan utama, tetapi seluruh bagian tanaman berguna untuk kehidupan manusia, dimana batang sorghum dengan pengolahan yang benar dapat menghasilkan nira yang dapat diolah menjadi bioethanol, dan serasah daun dapat digunakan sebagai pakan ternak (Purnomohadi, 2006).

Indonesia tidak termasuk Negara penghasil sorghum, hal ini disebabkan karena produksi sorghum Indonesia rendah. Peningkatan produksi sorghum selama lima tahun sebesar 1581 ton. Indonesia merupakan salah satu Negara yang berpotensi untuk pengembangan sorghum yang dapat dilakukan dengan ekstensifikasi dan intensifikasi Direktorat Budidaya Serealia, 2013).

Kuantan Singingi merupakan salah satu Kabupaten di Propinsi Riau yang masih sangat jarang di temukan hasil penelitian mengenai tanaman Sorgum. Namun salah satu kendala yang dihadapi adalah kesuburan tanah. Menurut Dinas Tanaman Pangan Kuantan Singingi (2013), secara umum jenis tanah di Kabupaten Kuantan Singingi adalah Podsolik Merah Kuning (PMK), Latosol, Alluvial, Glei Humus. Menurut hasil kajian yang dilakukan pada tahun 2008 pada lahan-lahan tidur yang berada di berbagai kecamatan, $\mathrm{pH}$ tanah sekitar 4,5
- 5,5 dengan demikian sebagian besar lahan tidur tersebut bereaksi masam.

Hakim (1986), mengemukaka bahwa kelemahan dan ciri tanah PMK (Untisol merupakan tanah dengan $\mathrm{pH}$ rendah dan memiliki bahan organik rendah, keracunan $\mathrm{Al}$, defisisensi $\mathrm{P}$, dan miskin unsur hara mikro lainnya.

Tanah PMK dapat diberdayakan dengan menambahkan

pupuk yang tepat dan seimbang, pupuk yang digunakan dapat berupa pupuk organik. Hal ini dilakukan untuk meningkatkan produktivitas lahan yang akan berpengaruh kepada produksi tanaman sorgum. Bioboost merupakan pupuk organic yang dapat digunakan untuk menambah bahan organic pada tanah PMK.

Menurut Manuhuttu, Rehatta, dan Kailola (2014), menjelaskan bahwa Bioboost adalah pupuk hayati yang di dalamnya terkandung mikroorganisme yang sangat bermanfaat dalam proses dekomposisi bahan organik, seperti Azotobacter, Azospirillum, Bacillus sp., Pseudomonas sp., dan Cytophaga sp. Selain itu Bioboost juga mengandung hormone seperti Giberellin, Sitokinin, Kinetin, Zeatin, dan Auksin (IAA). Penggunaan Bioboost dapat menekan penggunaan pupuk anorganik sebesar $50 \%$ sampai dengan $60 \%$, mengikat $\mathrm{N}$ bebas di zona perakaran, mempercepat proses bio kimia tanah yang menghasilkan $\mathrm{P}$ dan $\mathrm{K}$ tersedia bagi tanaman yang mengakibatkan kesuburan tanah meningkat dan mempercepat waktu panen yang dapat memenuhi standar.

Bioboost juga menjadikan aerasi tanah menjadi lebih baik, sehingga kehidupan mikroorganisme tanah menjadi lebih terjamin. Bioboost juga mengandung unsur hara makro dan 
mikro. Tujuan Penelitian adalah untuk mengetahui pengaruh pupuk Bioboost

\section{METODOLOGI PENELITIAN}

Penelitian ini merupakan penelitian di lapangan yang dilakukan selama 4 bulan yang dimulai pada bulan November 2018 sampai dengan Februari 2019.

Benih sorgum varietas Numbu, pupuk Bioboost, Rabuk kandang sapi, Urea, TSP dan $\mathrm{KCl}$ adalah bahan yang digunakan pada penelitian ini.

Peralatan budidaya tanaman, dan alat tulis lainnya, merupakan peralatan yang digunakan dalam melaksanakan penelitian ini.

Rancangan Acak Kelompok (RAK) dipilih sebagai Rancangan Lingkungannya. Rancangan perlakuan yang diteliti adalah volume Pupuk

\section{HASIL DAN PEMBAHASAN}

\section{Tinggi Tanaman (cm)}

Tinggi tanaman sorghum yang diberi perlakuan Bioboost menunjukkan terhadap produktivitas sorgum (Sorghum bicolor L. Moench).
Biobost terdiri dari 5 perlakuan, dengan 3 kali ulangan. Analisis data menggunakan Sidik Ragam dan Uji beda rata rata perlakuan yang digunakan adalah Uji BNJ pada taraf $1 \%$. Taraf perlakuan Bioboost adalah:

$\mathrm{A}=$ Tanpa perlakuan

$\mathrm{B}=$ Pemberian Pupuk Biobost $120 \mathrm{ml}$ tanaman $^{-1}$

$\mathrm{C}=$ Pemberian Pupuk Biobost $240 \mathrm{ml}$ tanaman $^{-1}$

$\mathrm{D}=$ Pemberian Pupuk Biobost $360 \mathrm{ml}$ tanaman $^{-1}$

$\mathrm{E}=$ Pemberian Pupuk Biobost $480 \mathrm{ml}$ $\operatorname{tanaman}^{-1}$

Tabel 1. Rerata tinggi tanaman umur 68 HST dengan perlakuan berbagai volume pupuk Bioboost

Faktor (H) HerbaFarm Granul

\begin{tabular}{ll}
\hline A (Tanpa perlakuan) & $162,11 \mathrm{e}$ \\
B (Pemberian Pupuk Biobost $\left.120 \mathrm{ml} \mathrm{tanaman}^{-1}\right)$ & $175,44 \mathrm{~d}$ \\
C (Pemberian Pupuk Biobost $\left.240 \mathrm{ml} \mathrm{tanaman}^{-1}\right)$ & $179,11 \mathrm{c}$ \\
D (Pemberian Pupuk Biobost $\left.360 \mathrm{ml} \mathrm{tanaman}^{-1}\right)$ & $184,33 \mathrm{~b}$ \\
E (Pemberian Pupuk Biobost $\left.480 \mathrm{ml} \mathrm{tanaman}^{-1}\right)$ & $188,33 \mathrm{a}$ \\
\hline KK 0,16\% & BNJ 0,79 \\
\hline
\end{tabular}

Angka-angka pada kolom dengan huruf kecil yang sama tidak berbeda nyata menurut uji lanjut (BNJ) pada taraf $1 \%$.

Perlakuan tinggi tanaman terbaik terdapat pada perlakuan E yaitu 188,33 $\mathrm{cm}$, dan yang paling rendah adalah perlakuan A yaitu 162,11 cm.

Apabila dibandingkan dengan deskripsi tinggi tanaman sorgum varietas numbu yaitu $\pm 187 \mathrm{~cm}$. Maka dapat pengaruh nyata, dan hsil uji beda rata rata perlakuan dapat dilihat pada Tabel 1 . dianggap bahwa tinggi tanaman pada perlakuan $\mathbf{E}$ telah sesuai dengan deskripsi. Artinya bahwa volume pupuk Bioobost $480 \mathrm{ml}$ pertanaman (perlakuan E) ini telah mampu meningkatkan kesuburan tanah. Diduga mikroorganisme yang terkandung dalam Bioboost mampu 
melaksanakan peranannya denga baik untuk menyediakan unsur hara yang dibutuhkan oleh tanaman sorghum. Menurut Manuhuttu, Rehatta, dan Kailola (2014), melaporkan bahwa mikroorganisme unggul yang ada pada Bioboost dapat menambah ketersediaan Nitrogen, dapat memeprcepat dekomposisi bahan organic tanah, menguraikan residu pestisida, dan hormone yang terkandung dalam Bioboost juga berperan aktif dalam proses pertumbuhan dan perkembangan tanaman, dan aktif menyediakan unsur hara yang dibutuhkan tanaman melalui proses bio kimia di dalam tanah.

Azotobakter yang terkandung dalam Bioboost berperan dalam menambat $\mathrm{N}$, seperti yang dilaporkan oleh Rahmi (2014), mengatakan bahwa nitrogen aerobik non-simbiotik dapat diikat oleh azotobacter dalam jumlah yang cukup tinggi.

Sifat kesuburan tanah yang juga sangat penting yaitu sifat biologi tanah. Dari hasil penelitian ini terlihat bahwa apabila volume perlakuan pupuk Bioobost semakin tinggi, maka pertumbuhan tinggi tanaman juga akan semakin baik/tinggi. Sebaliknya apabila volume perlakuan pupuk Bioobost semakin rendah maka pertumbuhan tinggi tanaman akan semakin jauh dibawah deskripsi.

Bakteri azotobakter merupakan bakteri penambat nitrogen, apabila ketersedian nitrogen tercukupi atau terpenuhi, maka secara langsung juga akan berpengaruh terhadap pertumbuhan tanaman. Nitrogen sendiri sangat berperan pada pertumbuhan tanaman. Surtinah (2017) melaporkan bahwa tanaman jagung yang cukup mendapatkan Nitrogen akan tumbuh dan berkembang dengan baik terutama organ daunnya, dan Nitrogen digunakan tanaman untuk membentuk Klorofil yang berperan aktif dalam proses fotosintesis. Unsur nitrogen terdapat dalam bentuk protein, seperti yang dijelaskan oleh Darmawan (2010) sangat penting bagi tanaman. Pada pertumbuhan tanaman terjadi pembelahan sel dan protein merupakan bahan yang digunakan untuk membentuk dinding sel.

Pupuk Bioobost juga mengandung bakteri basillus. Basillus juga dapat menghasilkan enzim. Menurut Rahayu (1990) dalam Hatmanti (2000), mengatakan bahwa berdasarkan sifat pertumbuhannya, $B$. subtilis bersifat mesofilik. Bakteri B. subtilis membentuk protease, amilase, lipase, serta kutinase sebagai enzim pengurai dinding sel patogen.

Soesanto (2008), mengatakan bahwa bakteri antagonis $B$. subtilis di dalam tanah dengan menggunakan hasil buangan akar dan bahan tanaman mati untuk sumber nutrisinya. Bakteri akan membentuk Endospora bila lingkungannya tidak sesuai dengan yang dikehendakinya. Endospora berperan untuk menjaga ketahanan dalam kondisi lingkungan yang menekan. Avivi et.al. (2010), menambahkan bakteri B. subtilis juga efektif dalam melarutkan fosfat, sehingga tersedia bagi tanaman untuk digunakan pada periode pertumbuhan dan perkembangannya.

Tinggi tanaman pada perlakuan A yaitu $162,11 \mathrm{~cm}$, disebabkan oleh karena tidak diberikan penambahan pupuk Bioobost. Dimana pupuk Bioboost mengandung Bakteri yang dapat menambat nitrogen seperti azotobakter dan basillus. Basillus sendiri berperan untuk melarutkan fosfat. Fosfat dapat menjadi tersedia untuk perakaran.

Unsur fosfat sendiri memiliki peran dalam proses pertumbuhan awal dan pertumbuhan akhir. Agustina (2004), menjelaskan bahwa $\mathrm{P}$ berperan pada proses fosforilasi pada tanaman.. Lingga (2006), Posfor berperan untuk mempercepat pembungaan dan panen, dan pada tanaman jagung $\mathrm{P}$ sangat 
dibutuhkan untuk mendapatkan hasil yang optimum.
Umur Muncul Bunga (hst)

Hasil pengamatan terhadap umur muncul bunga dapat dilihat pada Tabel 2 .

Tabel 2. Rerata umur muncul bunga dengan perlakuan berbagai volume pupuk Bioboost

\begin{tabular}{cc}
\hline Faktor (H) HerbaFarm Granul & Rerata (hst) \\
\hline \hline A (Tanpa perlakuan) & $61,33 \mathrm{e}$ \\
B (Pemberian Pupuk Biobost $120 \mathrm{ml} \mathrm{tanaman}^{-1}$ ) & $63,22 \mathrm{~d}$ \\
C (Pemberian Pupuk Biobost 240 $\mathrm{ml} \mathrm{tanaman}^{-1}$ ) & $65,33 \mathrm{c}$ \\
D (Pemberian Pupuk Biobost 360 $\mathrm{ml} \mathrm{tanaman}^{-1}$ ) & $66,33 \mathrm{~b}$ \\
E (Pemberian Pupuk Biobost 480 $\mathrm{ml} \mathrm{tanaman}^{-1}$ ) & $68,22 \mathrm{a}$ \\
\hline KK 0,38\% & BNJ 0,70
\end{tabular}

Angka-angka pada kolom dengan huruf kecil yang sama tidak berbeda nyata menurut uji lanjut (BNJ) pada taraf $1 \%$.

Umur muncul bunga tercept pada perlakuan A yaitu 61,33 hst bukanlah nilai positif, malainkan nilai negatif terhadap perlakuan tersebut. Apabila dibandingkan dengan deskripsi umur muncul bunga sorgum varietas numbu yaitu \pm 69 hst. Maka dapat dianggap bahwa umur muncul bunga pada perlakuan A jauh lebih cepat dari deskripsi. Artinya bahwa dengan tidak menambahkan pupuk Bioobost (perlakuan A) maka tidak akan mampu memperbaiki kesuburan tanah. Apabila kesuburan tanah tidak dapat diperbaiki, maka akan mengganggu perumbuhan dan perkembangan tanaman. Hal inilah yang terjadi pada perlakuan A.

Pada perlakuan A, kondisi yang terjadi adalah tanaman stres karena kekurangan unsur hara, seperti unsur hara $N$ dan unsur hara $P$. Sehingga menunjukkan morfologi yang abnormal, seperti cepatnya umur muncul bunga dan pada pengamatan tinggi tanaman, pada perlakuan A juga merupakan perlakuan yang pertumbuhan atau tinggi tanamannya paling rendah.

Havlin et al, (2005), mengatakan N dan $\mathrm{P}$ harus diberikan dalam kondisi seimbang, karena kekurangan $\mathrm{N}$ dapat menyebabkan penyerapan $\mathrm{P}$ menjadi terhambat.
Menurut Wang et al. (2007) dan Homer (2008), efektivitas penyerapan $\mathrm{P}$ pada tanaman dapat terjadi apabila ketersediaan unsur $\mathrm{N}$ cukup di dalam zona perakaran.

Menurut Arifin et al (2010), menjelaskan bahwa tanaman akan memiliki tanggapan yang berbeda, hal ini sangat tergantung pda ketersediaan hara di dalam tanah, kebutuhan tanaman akan unsur hara tidak hanya pada salah satu unsur saja, tetapi seluruh unsur hara esensil yang tersedia akan saling berkiatan satu sama lain, akan terjadi interaksi positif maupun negative yang dipengaruhi oleh lingkungannya .

Berdasarkan tabel 2, yang paling lama umur muncul bunganya adalah perlakuan E yaitu 68,22 hst. Lebih lamanya umur muncul bunga pada perlakuan $\mathrm{E}$ bila dibandingkan dengan perlakuan lainnya bernilai positif. Apabila dibandingkan dengan deskripsi umur muncul bunga sorgum varietas numbu yaitu \pm 69 hst. Artinya umur muncul bunga telah hampir sesuai dengan deskripsi. Hal ini disebabkan karena pada perlakuan $\mathrm{E}$ dengan pemberian volume pupuk bioobost sebesar $480 \mathrm{ml}$ pertanaman telah mampu memperbaiki kesuburan tanah. Apabila kesuburan tanah dapat diperbaiki, maka akan 
mempengaruhi perumbuhan dan perkembangan tanaman.

Pupuk Bioobost selain mengandung bakteri azotobakter dan basillus, juga mengandung bakteri Azospirillum yang berperan memperbaiki kemampuan tanaman untuk berproduksi dengan adanya N2 atau melalui pembentukan hormon.

Menurut Wuriesyliane et al. (2013), bakteri Azotobacter sp. yang bersifat aerobik dan mampu mengubah nitrogen dalam atmosfer melalui proses biokimia diubah menjadi protein yang dibutuhkan tanaman. Azospirillum sp., Pseudomonas sp. dan Bacillus sp. Dengan peranannya masing masing dapat meningkatkan ketersediaan $\mathrm{N}$, dan dapat $\begin{array}{llr}\text { meningkatkan } & \text { serapan } & \text { hara, } \\ \text { meningkatkan } & \text { pertumbuhan } & \text { serta } \\ \text { produktivitas } & \text { tanaman. Penggunaan }\end{array}$ konsorsium bakteri (bioboost) dengan proses biokimia tanah akan meningkatkan kesuburan tanah. Kombinasi mikro bakteri dan pupuk organik dan anorganik dapat meningkatkan produktivitas lahan yang akan meningkatkan produksi tanaman baik kualitas maupun kuantitasnya. Konsorsium bakteri itu sendiri terdiri dari berbagai macam bakteri yang bermanfaat dalam proses pertumbuhan tanaman.

\section{Umur Panen (hst)}

Hasil uji BNJ umur panen sorghum dapat dilihat pada Tabel 3.

Tabel 3. Rerata umur panen dengan perlakuan berbagai volume pupuk Bioboost

\begin{tabular}{cc}
\hline Faktor (H) HerbaFarm Granul & Rerata (hst) \\
\hline \hline A (Tanpa perlakuan) & $92,22 \mathrm{e}$ \\
B (Pemberian Pupuk Biobost $\left.120 \mathrm{ml} \mathrm{tanaman}^{-1}\right)$ & $94,56 \mathrm{~d}$ \\
C (Pemberian Pupuk Biobost $\left.240 \mathrm{ml} \mathrm{tanaman}^{-1}\right)$ & $97,44 \mathrm{c}$ \\
D (Pemberian Pupuk Biobost $\left.360 \mathrm{ml} \mathrm{tanaman}^{-1}\right)$ & $101,33 \mathrm{~b}$ \\
E (Pemberian Pupuk Biobost 480 $\left.\mathrm{ml} \mathrm{tanaman}^{-1}\right)$ & $103,44 \mathrm{a}$ \\
\hline KK 0,27\% & BNJ 0,62 \\
\hline
\end{tabular}

Angka-angka pada kolom dengan huruf kecil yang sama tidak berbeda nyata menurut uji lanjut (BNJ) pada taraf $1 \%$.

Hasil yang sama dengan umur muncul bunga, cepat umur panen pada perlakuan A yaitu 92,22 hst bukanlah nilai positif, malainkan nilai negatif terhadap perlakuan tersebut. Apabila dibandingkan dengan deskripsi umur muncul bunga sorgum varietas numbu yaitu $\pm 100-105$ hst. Maka dapat dianggap bahwa umur panen pada perlakuan A lebih cepat dari deskripsi. Artinya bahwa pada perlakuan A terlihat bahwa kesuburan tanah tidak diperbaiki, karena pada perlakuan A pupuk Bioobost tidak diberikan.

Agustina (2004), mengatakan Hukum Minimum Leibig yang artinya :
"Laju pertumbuhan tanaman diatur oleh adanya faktor yang berada pada jumlah minimum dan besar kecilnya laju pertumbuhan ditentukan oleh peningkatan dan penurunan faktor yang berada dalam jumlah minimum tersebut". Yang menjelaskan bahwa kurang dan lebihnya nutrisi yang dibutuhkan tanaman akan berpengaruh terhadap pertumbuhan dan perkembangan tanaman. Pada perlakuan A dengan tidak diberikannya pupuk Biooobost ke tanah, akan mempengruhi hasil tanaman. Hal ini telah terlihat dari pengamatan tinggi tanaman, umur muncul bunga sampai umur panen. Dimana hasil 
yang tidak baik terdapat pada perlakuan A (tidak diberi pupuk Bioobost).

Berdasarkan tabel 3, umur panen yang lambat adalah perlakuan $\mathrm{E}$ yaitu 103,44 hst. Lebih lamanya umur panen pada perlakuan E bernilai positif. Apabila dibandingkan dengan deskripsi umur panen sorgum varietas numbu yaitu \pm 100-105 hst. Artinya umur panen telah sesuai dengan deskripsi. Hal ini disebabkan karena pada perlakuan $\mathrm{E}$ dengan pemberian volume pupuk bioobost sebesar $480 \mathrm{ml}$ pertanaman mampu memperbaiki kesuburan tanah melalui tugas pokok dan fungsi dari bakteri yang terkandung didalamnya (pupuk bioobost). Dari hasil penelitian, semakin besar jumlah volume yang diberikan, maka semakin baik perutmbuhan dan perkembangan pada tanaman sorgum.
Pupuk Bioobost mengandung bakteri azotobakter, basillus dan juga mengandung bakteri Pseudomonas yang termasuk kepada kelompok bakteri rhizosfer. Bakteri rhizosfer berperan untuk meningkatkan serapan hara, untuk pertumbuhan serta produktivitas tanaman. Keberadaan mikroorganisme juga mampu menguraikan residu pestisida di dalam tanah. Hal ini sesuai dengan pendapat Manuhuttu, Rehatta dan Kailola (2014), unsur hara makro dan mikro yang terkandung dalam Bioboost, dan mikroorganisme yang bermanfaat yang dimilikinya sangat membantu proses pertumbuhan dan perkembangan tanaman.

\section{Berat Biji Kering (gram/tanaman)}

Hasil uji BNJ terhadap berat biji kering dapat dilihat pada Tabel 4.

Tabel 4. Rerata Berat Biji Kering dengan perlakuan berbagai volume pupuk Bioboost

\begin{tabular}{cc}
\hline Faktor (H) HerbaFarm Granul & Rerata (gram/tanaman) \\
\hline \hline A (Tanpa perlakuan) & $32,63 \mathrm{e}$ \\
B (Pemberian Pupuk Biobost $\left.120 \mathrm{ml} \mathrm{tanaman}^{-1}\right)$ & $89,51 \mathrm{~d}$ \\
C (Pemberian Pupuk Biobost $\left.240 \mathrm{ml} \mathrm{tanaman}^{-1}\right)$ & $97,70 \mathrm{c}$ \\
D (Pemberian Pupuk Biobost $\left.360 \mathrm{ml} \mathrm{tanaman}^{-1}\right)$ & $105,68 \mathrm{~b}$ \\
E (Pemberian Pupuk Biobost $\left.480 \mathrm{ml} \mathrm{tanaman}^{-1}\right)$ & $113,61 \mathrm{a}$ \\
\hline KK 0,21\% & BNJ 0,52 \\
\hline
\end{tabular}

Angka-angka pada kolom dengan huruf kecil yang sama tidak berbeda nyata menurut uji lanjut (BNJ) pada taraf $1 \%$.

Berat biji kering yang terbaik terdapat pada perlakuan $\mathrm{E}$, hal ini disebabkan karena pada perlakuan $\mathrm{E}$ adalah perlakuan yang paling tinggi volume pupuk Bioobostnya. Apabila dikonversikan kedalam bentuk ton/hektar maka 113,61 gram/tanaman setara dengan 6,05 ton/hentar. Maka dapat dianggap bahwa Berat biji kering pada perlakuan E telah melebihi deskripsi. Dimana apabila bandingkan dengan deskripsi potensi Berat biji kering sorgum varietas numbu yaitu $\pm 4,0-5,0$ ton/hentar. Artinya bahwa volume pupuk Bioobost pada perlakuan $\mathrm{E}$ yang pada penelitian ini merupakan perlakuan yang terbaik apabila dilihat dari hasil penelitian ini. Hal ini karena Pupuk Bioobost merupakan pupuk organik yang dapat memperbaiki dan dapat meningkatkan kesuburan tanah, seperti memperbaiki sifat biologi dan kimia tanah.

Dari sifat biologi pupuk Bioobost mengandung bakteri azotobacter memiliki banyak peran, seperti salah satunya meningkatkan ketersediaan P. Arshad dan Frankenberger (1993, dalam Rahmi, 2013), peranan Azotobakter selain meningkatkan fiksasi $\mathrm{N}$, juga dapat meningkatkan $\mathrm{P}$ tersedia bagi tanaman 
yang berperan sebagai biokontrol sehingga kesehatan akar dan pertumbuhan tanaman akan menjadi lebih baik. Shende et al. (1977 dalam Rahmi, 2014), juga mengatakan Azotobacter sp. dapat mengendalikan penyakit tanaman, dengan menghasilkan senyawa anti antibiotik dan anti jamur. Pada proses perkecambahan benih, adanya senyawa dihasilkan oleh Azotobacter seperti vitamin $\mathrm{B}$, nikotin, asam pentotenat, IAA, dan GA.

Berdasarkan tabel 4, kurang baiknya hasil berat biji kering pada perlakuan A yaitu 32,63 gram/tanaman, disebabkan karena pada perlakuan A tidak diberikan penambahan pupuk Bioobost. Apabila dikonversikan kedalam bentuk ton/hektar maka 32,63 gram/tanaman setara dengan 1,74 ton/hentar. Maka dapat dianggap bahwa Berat biji kering pada perlakuan A sangat jauh dibawah deskripsi. Dimana apabila bandingkan dengan deskripsi potensi Berat biji kering sorgum varietas numbu yaitu $\pm 4,0-5,0$ ton/hentar. Artinya bahwa volume pupuk Bioobost pada perlakuan A pada penelitian ini merupakan perlakuan dengan hasil yang terendah. Hal ini karena pada perlakuan A tidak diberikan pupuk Bioobost, diaman pupuk Bioobost merupakan pupuk organik yang berperan dalam memperbaiki kesuburan tanah, seperti memperbaiki sifat fisika, kimia dan biologi tanah. Susanto (2002),

\section{KESIMPULAN}

Perlakuan Pupuk Bioobost berpengaruh yang nyata terhadap tinggi tanaman $(\mathrm{cm})$, dengan perlakuan terbaik terdapat pada perlakuan E (Pemberian Pupuk Biobost $480 \mathrm{ml} \mathrm{tanaman}^{-1}$ ) dengan tinggi tanaman $188,33 \mathrm{~cm}$.

Perlakuan Pupuk Bioobost berpengaruh yang nyata terhadap umur muncul bunga (hst), dengan perlakuan mengatakan sifat fisik, kimia, dan biologi tanah dapat diperbaiki dengan pemberian pupuk organik, sehingga aerasi dan porositas tanah menjadi lebih baik sehingga memberi peluang kepada akar untuk berkembang, dan meningkatkan aktivitas mikroorganisme tanah yang akan memberikan asam organic menjadi tersedia di dalam tanah.

Sifat biologi tanah yang baik mengakibatkan unsur hara akan tersedia yang akan mempengaruhi pertumbhan, perkembangan dan hasil tanaman. Hal ini sesuai dengan pendapat Dwidjosepoetro (1996), yang menyatakan bahwa pertumbuhan tanaman yang baik sebagai akibat dari unsur hara yang dibutuhkan tanaman itu cukup tersedia bagi tanaman.

Nugroho (2013), unsur hara yang ada di dalam pupuk dapat menambah kekurangan unsur hara dalam tanah yang terangkut pada waktu panen. Pupuk yang diberikan dalam bentuk padat, cair maupun gas kepada tanaman tujuan utamany adalah untuk menambah kekurangan unsur hara, sehingga tanaman dapat memanfaatkan unsur unsur tersebut menjadi organ organ yang berperan dalam menghasilkan makanannya.

Dahlan dan Kaharudin (2007), kemampuan akar berkembang dan menyerap unsur hara sangat dipengaruhi oleh kecukupsn unsur hara dalam tanah, aerasi tanah, dan struktur tanah.

terbaik terdapat pada perlakuan E (Pemberian Pupuk Biobost $480 \mathrm{ml}$ tanaman $^{-1}$ ) dengan umur muncul bunga 68,22 hst.

Perlakuan Pupuk Bioobost berpengaruh yang nyata terhadap umur panen (hst), dengan perlakuan terbaik terdapat pada perlakuan E (Pemberian 
Pupuk Biobost $480 \mathrm{ml}$ tanaman $^{-1}$ ) dengan umur panen 103,44 hst.

Perlakuan Pupuk Kosplus berpengaruh yang nyata terhadap Berat Biji Kering (gram/tanaman), dengan

\section{DAFTAR PUSTAKA}

Agustina. I, 2004, Dasar Dasar Nutrisi Tanaman. Rienka Cipta. Jakarta.

Arifin Fahmi, Syamsudin, Sri Nuryani H Utami dan Bostang Radjagukguk. 2010. Pengaruh interaksi hara nitrogen dan fosfor terhadap Pertumbuhan tanaman jagung (Zea mays. L) pada tanah regosol dan latosol. Berita Biologi 10(3).

Avivi, S., I.S Suyani, S. Winarco. 2010. Efek bakteri pelarut fosfat terhadap pertumbuhan Aspergillus flavus pada perkecambahan kacang tanah. Jurnal HPT Tropika 10(1): 64-72. ISSN 1411-7525.

Dahlan, F.H dan Khairudin. 2007. Pengaruh Penggunaan Pemberian Pupuk Bokashi Kotoran Sapi Terhadap Pertumbuhan dan Produksi Tanaman Jagung. Jurnal Agribisnis. Juni 2007. Vol. 3 No. 1. Jakarta.

Darmawan, Januar, 2010, Dasar-dasar Fisiologi Tanaman, SITC, Jakarta

Dinas Tanaman Pangan Kab. Kuantan Singingi. 2013. Laporan Tahunan. Dinas Tanaman Pangan Kabupaten Kuantan Singingi. Teluk Kuantan.

Direktorat Budi Daya Serealia. 2013. Kebijakan Direktorat Jenderal Tanaman Pangan dalam Pengembangan Komoditas Serealia untuk Mendukung Pertanian Bioindustri. Makalah disampaikan perlakuan terbaik terdapat pada perlakuan E (Pemberian Pupuk Biobost $480 \mathrm{ml}$ $\operatorname{tanaman}^{-1}$ ) dengan Berat Biji Kering 113,61 gram/tanaman setara dengan 6,05 ton $\mathrm{Ha}^{-1}$.

pada Seminar Nasional Serealia, Maros, Sulawesi Selatan.

Dwidjoseputro, D. 1996. Pengantar Fisiologi Tumbuhan. Gramedia. Jakarta.

FSD (Food Security Departement). 2003. Sorghum: postharvest operations. http://www.fao.org./inpho/compend /text/ch07.htm. diakses 12 Januari 2012.

Hakim, N. 1986. Dasar-Dasar Ilmu Tanah. Universitas Lampung. Lampung.

Hatmanti, A. 2000. Pengenalan Bacillus Spp. Oseana, 25(1): 31-41

Havlin JL, JD Beaton, SL Tisdale and WL Nelson. 2005. Soil Fertility and Fertilizers. An introduction to nutrient management. Seventh Edition. Pearson Education Inc. Upper Saddle River, New Jersey.

Homer ER. 2008. The effect of nitrogen application timing on plant available phosphorus. Thesis. Graduate School of The Ohio State University. USA.

\section{Lingga, P. 2006, Petunjuk Penggunaan} Pupuk, Penebar Swadaya, Jakarta.

Manuhuttu. A.P, H. Rehatta, dan J. J. G. Kailola. 2014. Pengaruh Konsentrasi Pupuk. 
Hayati Bioboost Terhadap Peningkatan Produksi Tanaman Selada (Lactuca sativa. L). Agrologia Jurnal Ilmu Budidaya Tanaman. Volume 3. Nomor 1. April 2014

Nugroho. 2013. Pupuk dan Cara Pemupukan Tanaman Cabai. Penebar Swadaya. Jakarta.

Purnomohadi, M. 2006. Potensi penggunaan varietas sorgum manis (Sorghum biclor L. Moench) sebagai tanaman pakan. Jurnal Penelitian Hayati, 4 (12): 41-44.

Rahmi. 2014. Kajian efektifitas mikroba azotobacter $s p$. sebagai pemacu pertumbuhan tanaman kakao (theobroma cacao l.).Jurnal galung tropika, 3 (2) mei 2014, hlmn 44-53

Reddy, B.V.S., S. Ramesh, S.T. Borikar, and H. Sahib. 2007. ICRISATIndian NARS partnership sorghum improvement research: strategies and impacts. Current Science 92(7):909-915.

\section{Rinsema, W.T., 1983. Pupuk dan Cara} Pemupukan. Terjemahan HM. Saleh. Penerbit Bhatara Karya Aksara. Jakarta.
Soesanto, L. 2008. Pengantar Pengendalian Hayati Penyakit Tanaman, Suplemen ke Gulma dan Nematoda. Rajawali Pers. 573 p.

Susanto, R. 2002. Penerapan Pertanian Organik. Permasyaraakatan dan Pembangunannya. Penerbit Kanisius. Yogyakarta.

Surtinah, S. 2017. Potensi Hasil Jagung Manis (Zea Mays Saccharata, Sturt) Dengan Pemberian Paket Teknologi Pupuk Dan Zat Pengatur Tumbuh. Jurnal BiBieT, 2(1), 3744.

Wang YP, BZ Houlton and CB Field. 2007. A model of biogeochemical cycles of carbon, nitrogen, and phosphorus including symbiotic nitrogen fixation and phosphatase production. Global Biogeochemical Cycles 21, 1018-1029.

Wuriesyliane, Nuni , G. Madjid, A. dan Putu. 2013. Pertumbuhan dan Hasil Padi pada Inseptisol Asal Rawa Lebak yang Diinokulasi Berbagai Konsorsium Bakteri Penyumbang Unsur Hara. Lahan Suboptimal. 10 (2) 21-24 